\title{
Device associated -health care associated infections monitoring, prevention and cost assessment at intensive care unit of University Hospital in Poland (2015-2017)
}

Wieslawa Duszynska ${ }^{1 *} \mathbb{B}$, Victor Daniel Rosenthal ${ }^{2}$, Aleksander Szczesny ${ }^{1} \mathbb{D}$, Katarzyna Zajaczkowska ${ }^{3} \mathbb{D}$, Michal Fulek ${ }^{3}$ id and Jacek Tomaszewski ${ }^{3}$ (D)

\begin{abstract}
Background: Device-associated health care-associated infections (DA-HAls) in intensive care unit (ICU) patients constitute a major therapeutic issue complicating the regular hospitalisation process and having influence on patients' condition, length of hospitalisation, mortality and therapy cost.

Methods: The study involved all patients treated $>48 \mathrm{~h}$ at ICU of the Medical University Teaching Hospital (Poland) from 1.01.2015 to 31.12.2017. The study showed the surveillance and prevention of DA-HAls on International Nosocomial Infection Control Consortium (INICC) Surveillance Online System (ISOS) 3 online platform according to methodology of the INICC multidimensional approach (IMA).

Results: During study period 252 HAls were found in 1353 (549F/804M) patients and 14,700 patient-days of hospitalisation. The crude infections rate and incidence density of DA-HAls was $18.69 \%$ and $17.49 \pm 2.56 / 1000$ patient-days. Incidence density of ventilator-associated pneumonia (VAP), central line-associated bloodstream infection (CLA-BSI) and catheter-associated urinary tract infection (CA-UTI) per 1000 device-days were $12.63 \pm 1.49$, $1.83 \pm 0.65$ and $6.5 \pm 1.2$, respectively. VAP(137) constituted 54.4\% of HAls, whereas CA-UTI(91) 36\%, CLA-BSI(24) 9.6\%.The most common pathogens in VAP and CA-UTI was multidrug-resistant (MDR) Acinetobacter baumannii (57 and 31\%), and methicillin-resistant Staphylococcus epidermidis (MRSE) in CLA-BSI (45\%). MDR Gram negative bacteria (GNB) 159 were responsible for $63.09 \%$ of HAls. The length of hospitalisation of patients with a single DA-HAI at ICU was 21(14-33) days, while without infections it was 6.0 (3-11) days; $p=0.0001$. The mortality rates in the hospitalacquired infection group and no infection group were $26.1 \%$ vs $26.9 \% ; p=0.838 ;$ OR 0.9633;95\% Cl (0.6733-1.3782). Extra cost of therapy caused by one ICU acquired HAI was US\$11,475/Euro 10,035. Hand hygiene standards compliance rate was 64.7\%, while VAP, CLA-BSI bundles compliance ranges were 96.2-76.8 and 29-100, respectively.

* Correspondence: wieslawa.duszynska@umed.wroc.pl

'Department and Clinic of Anaesthesiology and Intensive Therapy, Wroclaw Medical University, L.Pasteura Street 1, 50-367 Wroclaw, Poland

Full list of author information is available at the end of the article

C C The Author(s). 2020 Open Access This article is licensed under a Creative Commons Attribution 4.0 International License, which permits use, sharing, adaptation, distribution and reproduction in any medium or format, as long as you give appropriate credit to the original author(s) and the source, provide a link to the Creative Commons licence, and indicate if changes were made. The images or other third party material in this article are included in the article's Creative Commons licence, unless indicated otherwise in a credit line to the material. If material is not included in the article's Creative Commons licence and your intended use is not permitted by statutory regulation or exceeds the permitted use, you will need to obtain permission directly from the copyright holder. To view a copy of this licence, visit http://creativecommons.org/licenses/by/4.0/ The Creative Commons Public Domain Dedication waiver (http://creativecommons.org/publicdomain/zero/1.0/) applies to the data made available in this article, unless otherwise stated in a credit line to the data. 


\begin{abstract}
(Continued from previous page)
Conclusions: DA-HAls was diagnosed at nearly $1 / 5$ of patients. They were more frequent than in European Centre Disease Control report (except for CLA-BSI), more frequent than the USA CDC report, yet less frequent than in limited-resource countries (except for CA-UTI). They prolonged the hospitalisation period at ICU and generated substantial additional costs of treatment with no influence on mortality. The Acinetobacter baumannii MDR infections were the most problematic therapeutic issue. DA-HAls preventive methods compliance rate needs improvement.
\end{abstract}

Keywords: Health care associated infections, DA-HAls, ISOS, Length of stay, Bundle, ICU

\section{Background}

Monitoring hospital infections is one of the most important elements in the prevention and control of device-associated health care-associated infections (DAHAIs). Ss shown in scientific literature, monitoring can lead to DA-HAIs reduction if implemented with a multidimensional approach [1, 2]. Hospital infections, which complicate the regular hospitalisation process, are a major therapeutic issue leading to compromising patients' condition (sometimes increased mortality), prolonged treatment periods and increased hospitalisation costs $[3,4]$.'Intensive care unit (ICU) nosocomial infections are more commonly associated with invasive treatment and diagnostic techniques as well as using lifesupporting or monitoring devices directly or indirectly. Nevertheless, infection risk factors were also found to be present on admission $[5,6]$. According to published data, over $50 \%$ of ICU patients are infected $[7,8]$. It was also found that DA-HAIs concern about $24.3-27.6 \%$ of ICU patients $[6,9]$. Additionally, geographic region, country income and hospital type influence the frequency of DAHAIs worldwide [10-14]. Monitoring of hospital infections in Poland was initiated by the Polish Society of Hospital Infections in 1999 and remains effective due to their cooperation with the European Centre for Disease Prevention and Control (ECDC) [15-17]. Even though Poland has been developing its infection control system quickly and effectively, few data has been published in English on hospital-acquired infections in patients treated at Polish ICUs [8, 9, 15-17].

The International Nosocomial Infection Control Consortium (INICC) network operates by means of an online surveillance system - the INICC Surveillance Online System (ISOS) 3- and a systematic multidimensional approach - the INICC Multidimensional Approach (IMA) - whose effectiveness for reduction of DA-HAI rates has been shown in the scientific literature [18-23]. The IMA is a system aimed to measure and reduce DA-HAI rates, mortality, LOS, costs, bacterial resistance and antibiotic consumption that comprises the simultaneous implementation of 6 components: (1) bundles, (2) education and training, (3) online outcome surveillance of DA-HAI rates and their adverse consequences; (4) online process surveillance to evaluate compliance with bundles; (5) online feedback of DA-HAI rates and their adverse consequences; and (6) online performance feedback. The ISOS applies the definitions of DA-HAIs developed by the Centre for Disease Prevention and Control /National Healthcare Safety Network (CDC/NHSN) and standardized methodologies, thereby promoting applied research and evidence-based infection prevention practices [1]. ISOS, implemented in more than 700 ICUs in 66 countries (predominantly developing and underfunded), has proven to be a very useful tool in DA-HAIs surveillance $[1,11]$.

The aim of this study is to show the results of active prospective surveillance and monitoring of infections, as well as to evaluate the compliance with preventive guidelines using INICC ISOS3 platform modules: Surveillance of HAIs-Full data-Adults and Paediatric ICU and Monitoring Infection Control Practices including Monitoring Compliance with Hand Hygiene (HH), Monitoring Compliance of ventilator-associated pneumonia (VAP), central line-associated bloodstream infection (CLA-BSI), and catheter-urinary tract infection (CAUTI) Prevention Bundle.

\section{Methods \\ Data collection}

The observational prospective study involved 1353 patients treated at Wroclaw Medical University Teaching Hospital in their ICU from 1/01/2015 to 31/12/2017. Preventive guidelines were evaluated in the last year of the observational period. The study protocol was approved by the Bioethics Committee of Wroclaw Medical University (No: KB-605/2016) in accordance with the Declaration of Helsinki. All analysed data (including laboratory results obtained from the patients during routine patients care and infections monitoring) entered into ISOS was previously anonymised and a statement covering patients data confidentiality was fully respected during manuscript preparation. In consequence, no consent or statement was needed. Consent from the local Institutional Bioethics Committee also included approval for publication of the data. Data concerning DA-HAIs was compared with the results of international reports 
of NHNS [10], INICC [24], ECDC [25] and our own earlier study.

The following data was entered and collected on the ISOS3 platform: age, sex, reason of hospitalisation, use of respirator support in patients with a tracheal tube or a tracheotomy tube, use of catheter in central line as well as urinary catheters, time of admission and discharge from the ICU, result of treatment, date of diagnosis and clinical presentation of a hospital infection and following particular guidelines in the prevention of infections called VAP, CA-UTI, CLA-BSI "bundles" as well as following hand hygiene standards.

\section{Clinical and microbiological diagnosis of DA-HAls}

DA-HAIs were diagnosed in patients hospitalised $>48 \mathrm{~h}$, based on clinical symptoms, infection markers [C-reactive protein (CRP), procalcitonin (PCT), leukocytosis], diagnostic imaging (chest $\mathrm{X}$-ray) and microbiological test results (blood, tracheal aspirate, central venous catheter tip, urine) according to CDC/INICC guidelines and their yearly updates $[1,26]$. All materials submitted for microbiological analysis were sampled and assessed qualitatively and quantitatively according to accepted European Union standards. Microbiological diagnoses were performed at University Hospital Microbiology Laboratory which implemented and applied the recommendation of the European Committee on Antimicrobial Susceptibility Testing (EUCAST) [27]. Additionally, susceptibility of microorganisms with Minimal Inhibitory Concentration (MIC) and resistance mechanisms assessment were determined and interpreted in accordance with the applicable recommendations of EUCAST [27]. A highly multiplexed, rapid point-of-care PCR test for respiratory pathogens and blood pathogens (FILMARRAY respiratory Panel and Blood Culture Identification Panel, BioFire Diagnostics USA) were used in early microbiological diagnosis. Two doctors working at the ICU and a microbiologist were involved in diagnosing the infection.

\section{Epidemiological indicators}

Epidemiological indicators were assessed as follow: DAHAIs incidence density $=$ number of DA-HAIs/ 1000 patient-days; VAP incidence density = number of VAP/ 1000 mechanical ventilator (MV)-days; CLA-BSI incidence density $=$ number of CLA-BSIs/ 1000 central line (CL)-days; UTI incidence density = number of UTIs/ 1000 urinary catheter (UC)-days; Infections rate $(\%)=$ number of infections/ number of patients hospitalised in a given time frame; Device utilisation ratio $(D U-R)=$ number of days of $\mathrm{MV}, \mathrm{CL}$ or $\mathrm{UC} /$ number of patientdays in a given time frame $\times 100$ [1].

Additionally, a percentage of specific clinical presentations of infections among the general number of HAIs was assessed, and an analysis of pathogens causing particular clinical presentations of infections and multidrug resistance assessment was conducted.

\section{Compliance with HAls preventive bundles and hand hygiene standard}

The study analyses data concerned with compliance with VAP, CA-UTI, CLA-BSI preventive "bundles", which were entered into the system at least once per week, showing a percentage of compliance with particular components of the preventive guidelines. Components of INICC Infection Control Bundle for VAP prevention included the following elements: 30-50 degree elevation of patients head, performed assessment of readiness to wean, subglottic suctioning, endotracheal cuff pressure of at least $20 \mathrm{~cm}$, comprehensive oral care with an antiseptic solution, condensate in ventilatory circuits, gastric over- distention, stress ulcer prophylaxis, deep vein thrombosis prophylaxis. Components of INICC bundle for UTI prevention are as follows: maximal barriers precautions when catheter was inserted, single-use lubricant used, sterile closed drainage system, urinary catheter never disconnected, urinary catheter above the leg, urinary collecting bag below the level of bladder, urinary collecting bag with less than $75 \%$ of capacity full. Components of INICC bundle for CLA-BSI prevention are as follows: hand hygiene compliance before catheter insertion or manipulation, maximum sterile precaution barrier during insertion, chlorhexidine skin antisepsis, daily assessment of the need of catheter, presence of sterile dressing, type of dressing, good condition of dressing, single use flushing, type of set connector, type of bag container for intravenous infusion, administration equipment date, daily bath with a $2 \%$ chlorhexidineimpregnated washcloth.

Moreover, the anonymous study assessed the baseline $\mathrm{HH}$ compliance rate by healthcare workers at ICU at a different work times every 3 months. Five moments for hand hygiene were checked: before patient contact, before aseptic procedures, after patient contact, after body fluid exposition risk, after contact with patient surroundings. Staff was aware of the checks, yet not specifically of when the checks were carried out. The study showed the percentage of staff following hand hygiene standards.

\section{Economic cost analysis based on a prolonged LOS}

As an economic cost analysis, the study compared the length of stay (LOS) in ICU patients with a single infection, as well as with multiple infections, with the LOS of patients without hospital infections. Based on a prolonged LOS (extra LOS) and the patient-day cost an additional cost resulting from hospital infections was calculated [1]. Total daily cost per one ICU patient was retrieved from the Financial Management of the hospital. Components of this costs are included as follows: 
human resources, medications, consumables, laboratory tests, investigation tests, administrative expenses assigned to ICU. Total daily cost per one ICU patient was assessed once a year. The hospital did not perform a detailed and statistical cost analysis per one individual patient as well as for infected and not infected patient. Our study used mean values of these costs between the years 2015 and 2017, which was $€ 669=$ US\$ 765. Total daily cost was entered into ISOS calculator in order to obtain cost analysis.

\section{Statistical analyses}

Statistical analyses were performed using the STATISTI CA program version 13.1(StatSoft Inc., Tulsa, USA) Data are presented as mean values \pm standard deviation (SD) or median and interquartile range (IQR). Descriptive statistics were computed for all study variables. Discrete variables are expressed as counts and percentage or median and IQR. Distribution of qualitative variables were analysed using Chi-square test, Person's chi-squared test, the Mann-Whitney $U$ test which were used adequately to the strength of the group. For multiple comparisons was also used the Kruskal- Wallis ANOVA test with post hoc analysis and Fieller test. $P<0.05$ was considered as statistically significant.

\section{Results}

Among the 1353 patients over the 14,700 patient-day hospitalisation period, 252 hospital infections were diagnosed. See Table 1 for patients' characteristics. DA-HAIs incidence density [mean $\pm \mathrm{SD} /$ median $(\mathrm{IQR})]$ was $17.49 \pm 2.56$ /17.13(16.13-18.68)/1000 patient-days. The crude infections rate of DA-HAIs was $18.62 \%$. VAP was the most commonly diagnosed DA-HAI found in 137 patients (54.4\%), followed by CA-UTI in 91 patients (36\%) and CLA-BSI at 24 patients (9.6\%).VAP incidence density [(median (IQR)]/1000 MV-days was 13.66 (12.01-13.77), whereas UTI 5.85(5.8-6.8)/1000 UC-days and CLA-BSI 1.63(1.47-2.09)/1000 CL-days. See Fig. 1 for VAP, UTI, CLA-BSI mean incidence density/ 1000 DU-R.

The most common pathogen in VAP and UTI was Acinetobacter baumannii MDR, comprising 53 and 31\% of the general number of pathogens, respectively. The most common etiologic agents of CLA-BSI were methicillin-resistant coagulase-negative staphylococci (MRCNS) strains comprising 45\%. See Fig. 2 for a detailed compilation of pathogens of different clinical presentations of DA-HAIs. During the study period Gram Negative Bacteria (GNB) were predominant 229(74. 6\%), whereas Gram Positive Bacteria (GPB) 62(20.2\%) and fungi $16(5.2 \%)$ were found less frequently. MDR GNB were responsible for 159 (63.09\%) of HAIs.

Mortality rate in patients with and without hospital infections was similar $26.1 \%$ vs $26.9 \%(p=0.838)$. HAIs in
Table 1 Patient characteristics. Data is showed as numerical values, percentage values, median values (IQR), 95\% Cl

\begin{tabular}{ll}
\hline Total number of patients, $\mathbf{n}$ & $\mathbf{1 3 5 3}$ \\
\hline Female, $\mathrm{n}(\%)$ & $549(40.56)$ \\
Male, $\mathrm{n}(\%)$ & $804(59.44)$ \\
Age years, (\%) & \\
$\quad 79-91$ & 17.48 \\
$65-78$ & 32.03 \\
$52-64$ & 23.9 \\
39-51 & 10.63 \\
Medical patients, $\mathrm{n}(\%)$ & $566(41.82)$ \\
Surgical patients, $\mathrm{n}(\%)$ & $787(57.9)$ \\
Total patient-days, $\mathrm{n}$ & 14,700 \\
Total mechanical ventilation -days, $\mathrm{n}$ & 11,310 \\
DU-R mechanical ventilation, (\%) & 76.41 \\
Total urinary catheter days, $\mathrm{n}$ & 13,039 \\
DU-R urinary catheter, (\%) & 88.75 \\
Total central vascular catheter days, $\mathrm{n}$ & 14,198 \\
DU-R central vascular catheter, (\%) & 96.74 \\
Total number died, $\mathrm{n}(\%)$ & $453(33.5)$ \\
LOS in ICU-days, $\mathrm{n}$ (IQR) & $7(3-15), 95 \% \mathrm{Cl}(11.13-12.65)$ \\
\hline
\end{tabular}

Abbreviations: $\mathrm{Cl}$ confidence interval range; $D U-R$ device utilization ratio; ICU intensive care unit; IQR interquartile range; LOS length of stay

ICU patients have no significant influence on mortality risk at ICU $(\mathrm{p}=0.838 / \mathrm{OR} 0.9633$;CI 0.6733-1.3782). Yet, one hospital infection acquired at ICU tripled the median LOS in comparison to the median LOS of patients with no infections $(p<0.0001 / 95 \%$ CI $4.011-5.646)$. In patients with multiple infections, the median LOS at ICU increased sixfold ( $\mathrm{p}<0.0001 / 95 \% \mathrm{CI} 2.532-3.304$ ). See Table 2 for the analysis of how DA-HAIs affected the length of ICU hospital stay and generated additional costs of treatment. See Table 3 for a comparative analysis of the incidence density of particular clinical presentations of hospital infections and data collected in international registers and own study [10, 24, 25, 28]. During the study period 960 opportunities for $\mathrm{HH}$ were checked and 154 visits were made at ICU for HAIs preventive bundle assessment. Baseline $\mathrm{HH}$ compliance of healthcare workers at ICU was $64.66 \%$, whereas compliance with components of HAIs bundles were assessed only separately. See Table 4 for juxtaposition profile compliance with VAP, CLA-BSI, CA-UTI and hand hygiene preventive bundles.

\section{Discussion}

In this study with prospective, continuous infections monitoring prevalence rate we found ICU acquired HAIs at $1 / 5$ of patients. In a multicentre European Prevalence of Infection in Intensive Care (EPIC) study (1992) it was 


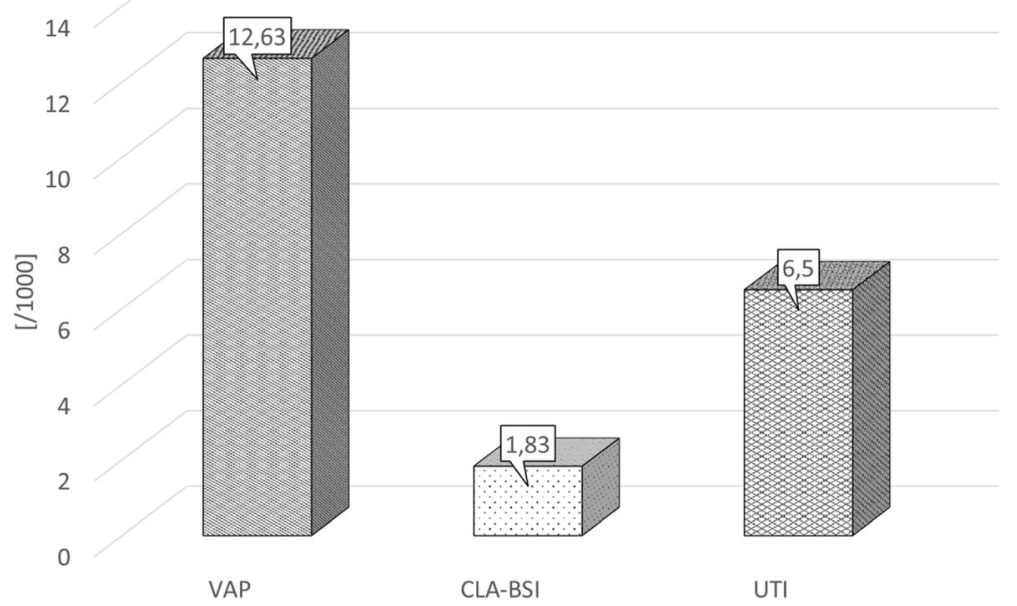

Fig. 1 VAP, CLA-BSI and UTI mean incidence density/1000 DU-R. Abbreviations: UTI, catheter-associated urinary tract infection; CLA-BSI, central line-associated bloodstream infection; DU-R, device utilization ratio; VAP, ventilator-associated pneumonia

shown that infections were diagnosed in 4501 patients $(48.8 \%)$ and ICU- acquired HAIs in 2064 patients among 10,038 patients $(20.6 \%$, nearly to our results) [29]. A pioneering study on infections at our ICU involving 560 patients hospitalised from 1995 to 1996 showed that HAIs affected $48 \%$ of patients, but ICU-acquired HAIs were diagnosed more frequently (33\%) compared with this study [30]. The crude infection rate (prevalence of HAIs) analysed in our study was lower than in the previously published study carried out in our centre involving 847 patients treated from 2007 to 2010, in which they were 24.3\% [9]. In the Polish point prevalence study (according to ECDC methodology) carried out in 2012-2013, the prevalence of HAIs in ICU patients was $430 / 945$ (39.8\%), significantly higher than in our study [15]. Moreover, the overall HAIs rate found during a ten-year study at the ICU in the District Hospital in Poland (27.6\%) was also higher than our present result [6]. In the Polish multicenter study conducted 2013-2015 in seven Polish ICUs based on active surveillance the

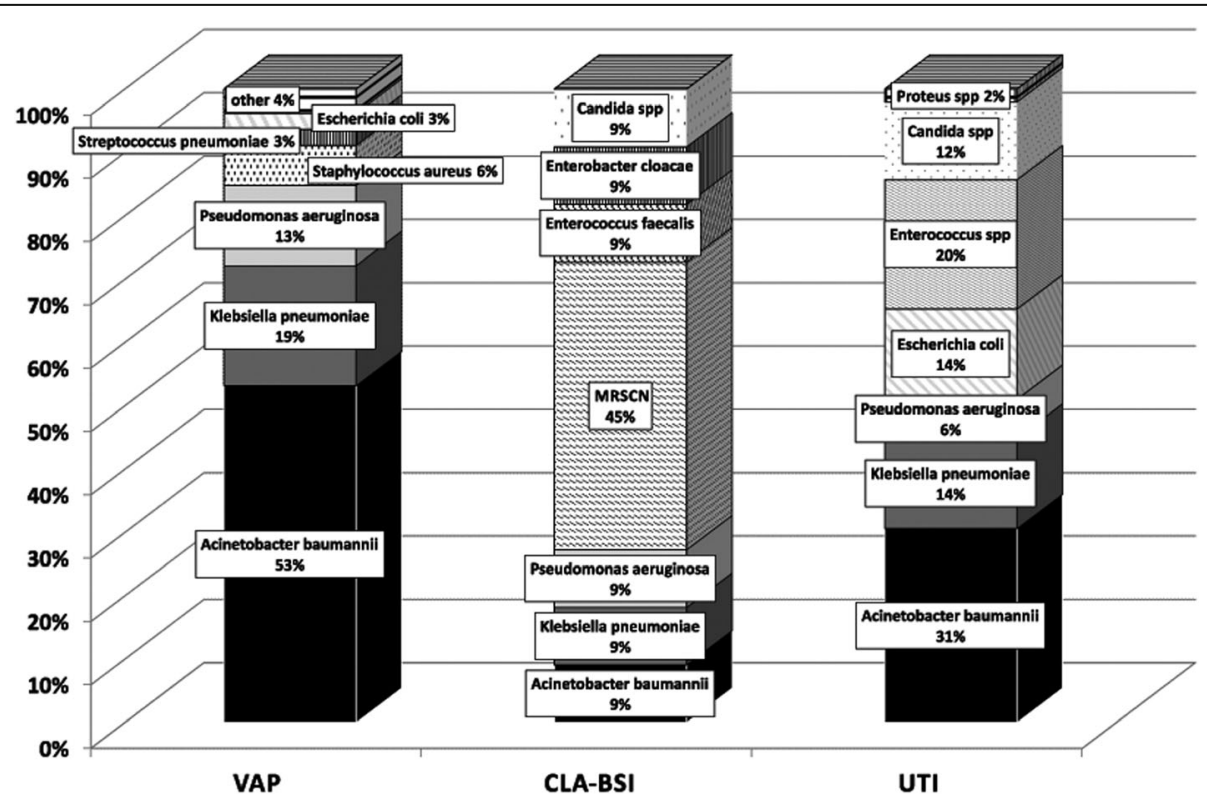

Fig. 2 Pathogens responsible for different clinical presentations of DA-HAls. Abbreviations: UTI, catheter-associated urinary tract infection; CLA-BSI, central line-associated bloodstream infection; DA-HAl, device-associated health care-associated infections; VAP, ventilator-associated pneumonia 
Table 2 Influence of device-associated health care-associated infections on length of stay and additional cost of therapy. Data is showed as numerical values, median values (IQR), 95\% Cl

\begin{tabular}{|c|c|c|c|c|}
\hline & $\begin{array}{l}\text { Average LOS of patient } \\
\text { with HAls, } \\
\mathrm{n}(\mathrm{IQR}), 95 \% \mathrm{Cl}\end{array}$ & $\begin{array}{l}\text { Average LOS of } \\
\text { patient with no HAls } \\
n(\text { IQR), } 95 \% \mathrm{Cl}\end{array}$ & $\begin{array}{l}\text { Extra LOS of patient } \\
\text { with HAIs, } n\end{array}$ & $\begin{array}{l}\text { Extra cost of therapy } \\
\text { caused by HAls }\end{array}$ \\
\hline One infection & $21(14-33), 95 \% \mathrm{Cl}(27.72-28.7)$ & $6.0(3-11), 95 \% \mathrm{Cl}(8.27-9.42)$ & 15 & $\begin{array}{l}\text { US\$ } 11,475 \\
€ 10,035\end{array}$ \\
\hline Multiple infections & $39.5(31-51), 95 \% \mathrm{Cl}(35.68-49.41)$ & $6.0(3-11), 95 \% \mathrm{Cl}(8.27-9.42)$ & 33.5 & $\begin{array}{l}\text { US\$ } 25,627 \\
€ 22,411.5\end{array}$ \\
\hline VAP & $27(15-41), 95 \% \mathrm{Cl}(26.77-34.39)$ & $6.0(3-11), 95 \% \mathrm{Cl}(8.27-9.42)$ & 21 & $\begin{array}{l}\text { US\$ } 16,065 \\
€ 14,049\end{array}$ \\
\hline CLA-BSI & $30(20-43), 95 \% \mathrm{Cl}(23.13-38.59)$ & $6.0(3-11), 95 \% \mathrm{Cl}(8.27-9.42)$ & 24 & $\begin{array}{l}\text { US\$ } 18,360 \\
€ 16,056\end{array}$ \\
\hline CA-UTI & $29.00(14.5-43.5), 95 \% \mathrm{Cl}(26.69-35.76)$ & $6.0(3-11), 95 \% \mathrm{Cl}(8.27-9.42)$ & 23 & $\begin{array}{l}\text { US\$ } 17,595 \\
€ 15,387\end{array}$ \\
\hline $\begin{array}{l}\text { Additional cost of therapy } \\
\text { in observed period }\end{array}$ & & & & $\begin{array}{l}\text { US\$ } 1413,480 / 1 \text { year } \\
€ 1236,378 / 1 \text { year }\end{array}$ \\
\hline
\end{tabular}

Legend: real mean value cost of one patient-day was $€ 669=$ US\$ 765

Abbreviations: CA-UTI catheter-associated urinary tract infection; $C l$ confidence interval; $C L A-B S I$ central line-associated bloodstream infection; $D A-H A I$ deviceassociated health care-associated infections; IQR interquartile range; LOS length of stay; $n$ number of patients with infections or number of days; VAP ventilator-associated pneumonia

incidence of HAIs $(22.6 \%)$ was similar to our results [16]. Reversely, the ECDC HAIs register analysed data from 2014 (on the basis The European Surveillance System -Tessy) showed that the HAIs incidence rate in 87, 337 patients hospitalised $>24 \mathrm{~h}$ in 1290 European ICUs was twice lower (8\%) than in our study [31]. In 2016 and 2017, according to the ECDC registers, the frequency of ICU acquired HAIs was on roughly the same level (8.4 and $8.3 \%)$ and still lower than our results $[25,31]$. In a study conducted in the USA, the prevalence of HAIs in ICU patients was $34.5 \%$, DA-HAIs (VAP, UTI,CLA-BSI) accounted for $25.6 \%$ of all HAIs [14]. Nevertheless, the rate of ICU acquired HAIs was not assessed [14]. The incidence density of HAIs in our study was lower than in the previously published study carried out in our centre $(21.9 / 1000)$ [9]. The same study showed that the VAP incidence density was twice higher than the current results and the CLA-BSI incidence density was four times higher [9]. Incidence density of VAP in our study is lower than our earlier published results (11.15/9.34/ $10.23 / 1000)$ whereas incidence density of CA-UTI is still on the same high level $(6.44 / 6.84 / 7.16 / 1000)$ [32, 33]. In other Polish observational study VAP (15.5/1000) and CLA-BSI (5/1000) incidence density was higher and CAUTI (1.9/1000) incidence density was lower than in our study [34]. Results of our study were similar to results of other studies when VAP was the most commonly diagnosed DA-HAI $[6,8,10-12,15]$. Our results showed that clinical presentations of HAIs were more frequent than those found in European Centre Disease Control report (except for CLA-BSI), more frequent than the USA CDC report, yet less frequent than in limited-resource countries (except for CA-UTI) [10, 24, 25].

Our observations confirm that hospital infections considerably prolonged the LOS at ICU [9-11]. According to a multicenter worldwide study (2017) Prevalence and Outcomes of Infection among patients in ICUs (EPIC III) findings, median (IQR) length of ICU stay was 10(328) days whereas in infected patients it was 15(6-36), and 5(2-17) days in not infected [12]. LOS in our study in comparison to EPIC III findings was longer in regards to infected and nearly the same in not infected patients.

Table 3 Comparison of incidence density rate of DA- HAls with data from international registers INICC (2010-15), NHSN (2013), ECDC (2017) and own surveys

\begin{tabular}{llll}
\hline & VAP & CAUTI & CLA-BSI \\
\hline ICU Wroclaw UH HELICS [28] & $18.2(15.5-21.6)$ & $4.8(3.5-6.5)$ & $4.01(2.8-5.6)$ \\
NHSN [10] & $0.9(0.8-1.0)^{*}$ & $1.7(1.6-1.8)^{*}$ & $0.8(0.8-0.9)^{*}$ \\
ECDC [25] & $9,5(2.5-20.4)^{* *}$ & $3.6(0.0-5.0)$ & $3.7(0.7-4.7)$ \\
INICC [24] & $14.1(13.8-14.4)^{*}$ & $5.1(5.0-5.2)^{*}$ & $5,05(4.9-5.2)^{*}$ \\
ICU Wroclaw UH (2015-2017) & $12.63(12.01-13.77)$ & $6.5(5.8-6.8)$ & $1.83(1.47-2.08)$ \\
\hline
\end{tabular}

Legend:*Data concern to medical -surgical ICU; Data is showed as mean values, percentile values/95\%Cl confidence interval or minimal and maximal values ** Abbreviations: CA-UTI catheter-associated urinary tract infection; CLA-BSI central line-associated bloodstream infection; ECDC European Centre for Disease Prevention and Control; ICU intensive care unit; INICC International Nosocomial Infection Control Consortium; HELICS The Hospitals in Europe Link for Infection Control through Surveillance; NHSN US National Healthcare Safety Network; UH University Hospital; VAP ventilator-associated pneumonia; 


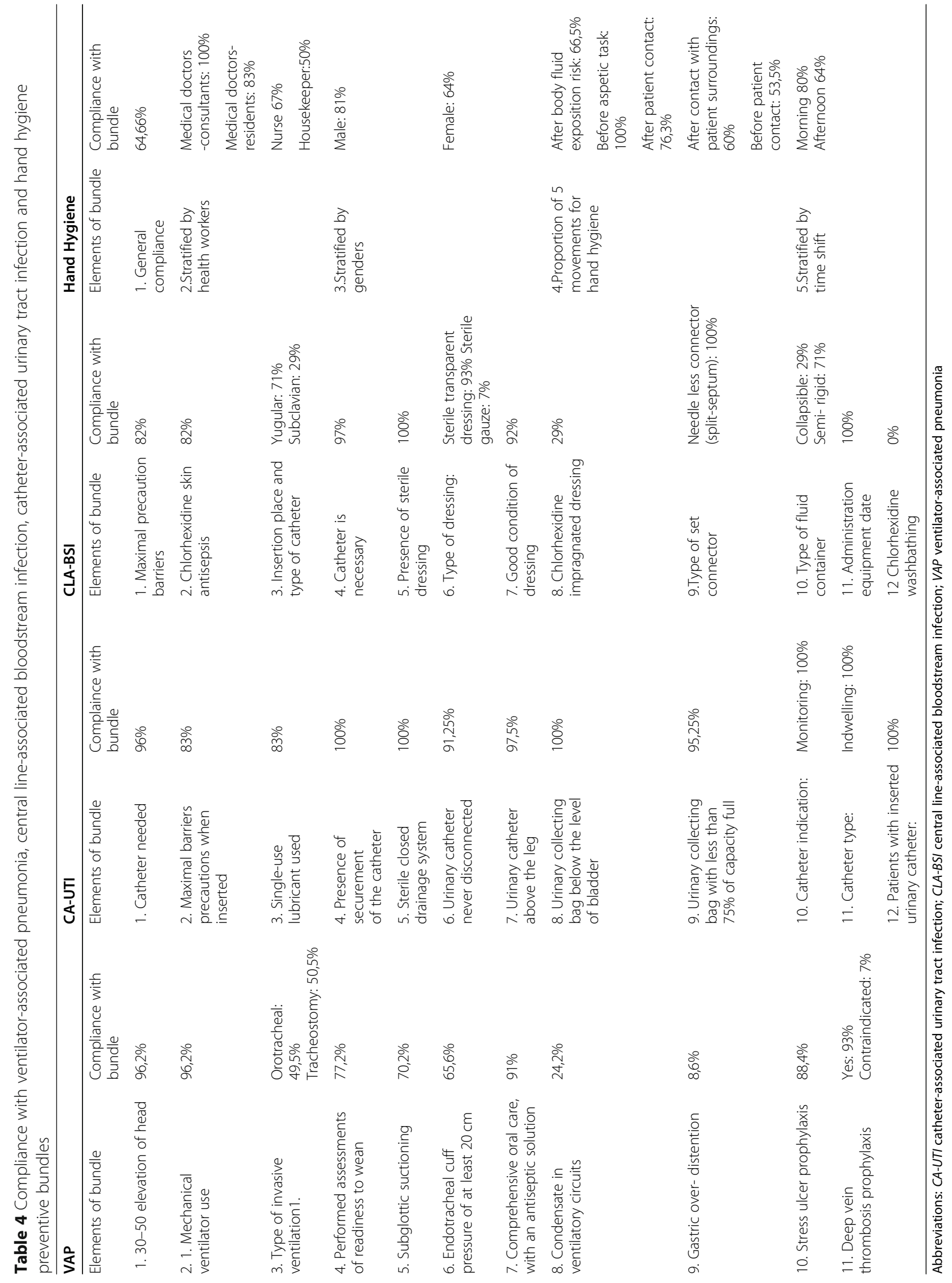


The increase in the mortality rate due to DA-HAIs was shown in several studies [35-37]. In the first EPIC study the mortality rate in patients with infections (the comparison did not specify clinical form of DA-HAIs) was twice higher than in patients without infections (25\% vs. $11 \%, p<0.01)$ [29]. Higher mortality rate at infected patients $(23.6 \%)$ than in not infected $(9.6 \%)$ was found also in EPIC III study. However, this study did not specify mode of infection acquisition (community, ICU- acquired, hospital- acquired) in this analysis [12]. Another Polish study did not show, similarly to ours, any statistical difference in mortality in patients with and without infections $(35.58 \%$ vs $39.23 \%, p=0.5674)$ [38]. In recent years, an increase of GNB infections in hospital practice worldwide has been observed, which confirms the results of our study [12, 25, 31, 39]. Distribution of isolated microorganisms according to mode of acquisition infections in EPICIII study showed that at ICU-acquired infections GNB consisted 77.9\%, GPB 31.3\%, fungi 18.5\%. In the same study infections caused by Pseudomonas spp.(23\%), Klebsiella spp. (22.6\%), Acinetobacter spp. $(16,6 \%)$ were found more frequently [12]. Acinetobacter infections (independently from acquisition) were found more frequently in Asia/Middle East 25,6\%, Eastern Europe $22.9 \%$, Africa $15.8 \%$, and very rarely in Western Europe 3,5\%, Central/South America 9,4\%, North America 1.0\%, Australasia 1,9\% [12]. Predominance of GNB in EPIC III study is similar to our study $(77.9 \%$ vs 74.6\%). The high percentage of Acinetobacter baumannii infections observed in our study is similar to that in hospitals in Greece and Italy and in another Polish centre, and is epidemic in its character [38, 40,41]. Contrary to our findings, the most frequently isolated microorganism in ICU pneumonia episodes in Europe was Pseudomonas spp (19.9\%), whereas Acinetobacter spp. reached only 4.5\%. Acinetobacter spp. spreading at patients with ICU pneumonia varied and reached 39.5\% in Romania, 20\% Slovacia, whereas 0\% in Belgium, $1.5 \%$ in Germany, $1.8 \%$ in UK, 2.7\% in France [25]. The European Antimicrobial Resistance Surveillance Network (EARS-NET) report from 2018 showed that Acinetobacter spp resistance to carbapenems was higher in Croatia 95.5\%, Greece 92.4\%, Romania $85.3 \%$, Italy $79.2 \%$, Poland $67.3 \%$, Spain $54.3 \%$ and lower in Netherlands $4.6 \%$, Germany $4.4 \%$, Belgium $3.8 \%$, Sweden $3.7 \%$, UK $1.8 \%$ [42]. The EPIC III study found that infections caused vancomycin resistant Enterococcus, Klebsiella pneumoniae resistant to third generation cephalosporines and carbapenems, and carbapenem resistant Acinetobacter spp. was independently associated with a higher risk of death compared to other microorganisms [12]. Since Acinetobacter baumannii MDR/ carbapenem resistant infections (data not shown) were predominant in our patients, it may be the cause of such high mortality [43]. In regards to the last analysed elements of the study, it was found in several studies that HAIs preventive bundles are associated with DAHAIs reduction $[44,45]$. It has been demonstrated that implementation of specific INICC program directed to improve hand hygiene in limited resource countries improved $\mathrm{HH}$ compliance and contributed to the reduction DA-HAIs and mortality [46, 47]. Baseline HH compliance $(64.66 \%)$ of ICU staff in our study was similar to earlier INICC data in which $\mathrm{HH}$ compliance rates were 9-75\% [46]. Limitations of the study: firstly, because it is only one centre, study results can be different in relation to geographic regions and type of departments. Secondly, only compliance with bundle was assessed, not its influence on infection rate, given it was not the aim of the study. Thirdly, we did not assess and compare patients' conditions in infection group and without infections using scoring methods, since it is not included in ISOS INICC methodology. Finally, numerous factors influence ICU LOS and hospital costs. Nevertheless, we showed an economic cost analysis using methods according to earlier INICC data, on a basis extra LOS and daily cost per patient $[3,4]$.

\section{Conclusions}

Device associated hospital infections in our centre were found in nearly $1 / 5$ of treated patients. VAP constituted more than half of those infections. DA-HAIs occurred more frequently than in the USA (except for CLA-BSI), yet less frequently than in the developing countries (except for CA-UTI). They prolonged the length of hospital stay and generated additional treatment costs. However, HAIs had no influence on the mortality rate. Acinetobacter baumannii MDR infections proved to be the most problematic therapeutic issue. Detailed registering of hospital infections using ISOS3, creating, implementing and monitoring compliance with hygienic and preventive measures, as well as the analysis of obtained data and drawing conclusions considered in hospital management may prove useful in improving the quality of care and reducing hospital costs.

\footnotetext{
Abbreviations

CA-UTI: Catheter-associated urinary tract infection; CDC: Centre for Disease Prevention and Control; Cl: Confidence interval; CL: Central line; CLA-

BSI: Central line-associated bloodstream infection; CRP: C-reactive protein; DA-HAls: Device-associated health care-associated infections; DU-R: Device utilisation ratio; ECDC: European Centre for Disease Prevention and Control; EPIC: European Prevalence of Infection in Intensive Care; €: Euro;

EUCAST: European Committee on Antimicrobial Susceptibility Testing; GNB: Gram Negative Bacteria; GPB: Gram Positive Bacteria; HAls: Health careassociated infections; HH: Hand Hygiene; HELICS: The Hospitals in Europe Link for Infection Control through Surveillance; ICU: Intensive Care Unit; IMA: INICC multidimensional approach; INICC: International Nosocomial Infection Control Consortium; ISOS: INNIC Surveillance Online System; IQR: Interquartile range; LOS: Length of stay; MDR: Multidrug-resistant; MRSE: Methicillin-resistant Staphylococcus epidermidis; MRCNS: Methicillinresistant coagulase-negative staphylococcus; MV: Mechanical ventilator; NHSN: National Healthcare Safety Network; PCT: Procalcitonin; USA: The
} 
United States of America; UC: Urinary catheter; UH: University Hospital; US\$: US dollar; VAP: Ventilator-associated pneumonia

\section{Acknowledgments}

The authors would like to thank Lukasz Struzecki, Jakub Smiechowicz and Debora Lopez-Burgardt and all the INICC team for their help with this study.

\section{Authors' contributions}

VDR - conceived the study protocol; VDR, WD - coordinated the study; WD,VDR - supervised data collection; ASz, KZ, MF, JT - participated in data collection; WD, VDR - participated in data interpretation; WD, ASz, KZ, MF, JT carried out the literature search; WD,VDR - drafted the present manuscript; All the authors read and approved the final version of the manuscript and agree to be accountable for all aspects of the work.

\section{Funding}

No funding sources.

\section{Availability of data and materials}

The data collected and analysed during this study are available and can be accessed from Wieslawa Duszynska (e-mail: wieslawa.duszynska@umed.wroc.pl).

\section{Ethics approval and consent to participate}

Approval of this study was given by the Bioethics Committee of the Wroclaw Medical University, Poland (No: KB-605/2016). All collected data including mainly laboratory results obtained from the patients during routine patients care and infections surveillance was fully anonymised before analysis. Due to this fact, no consent or statement was needed. Local Bioethics Committee consent included also approval for the publication of the data.

\section{Consent to publication}

Not Applicable.

\section{Competing interests}

The authors declare that they have no competing interests.

\section{Author details}

'Department and Clinic of Anaesthesiology and Intensive Therapy, Wroclaw Medical University, L.Pasteura Street 1, 50-367 Wroclaw, Poland. ${ }^{2}$ International Nosocomial Infection Control Consortium, Buenos Aires, Argentina. ${ }^{3}$ The Students Scientific Association by Department and Clinic of Anaesthesiology and Intensive Therapy, Wroclaw, Poland.

\section{Received: 5 June 2020 Accepted: 6 October 2020}

Published online: 16 October 2020

\section{References}

1. Rosenthal VD. International nosocomial infection control consortium (INICC) resources: INICC multidimensional approach and INICC surveillance online system. Am J Infect Control. 2016:44:e81-90

2. Rosenthal VD. Health-care-associated infections in developing countries. Lancet. 2011;377:186-8.

3. Hiquera F, Rangel-Frausto MS, Rosenthal VD, et al. Attributable cost and length of stay for patients with central venous catheter-associated bloodstream infection in Mexico City intensive care units: a prospective, matched analysis. Infect Control Hosp Epidemiol. 2007;28:31-5.

4. Rosenthal VD, Guzman S, Migone O, Crnich CJ. The attributable cost, length of hospital stay, and mortality of central line-associated bloodstream infection in intensive care departments in Argentina: a prospective, matched analysis. Am J Infect Control. 2003;31:475-80.

5. Deptula A, Trejnowska E, Ozorowski T, Hryniewicz W. Risk factors for healthcare-associated infection in light of two years of experience with the ECDC point prevalence survey of healthcare-associated infection and antimicrobial use in Poland. J Hosp Infect. 2015:90:310-5.

6. Kolpa M, Walaszek M, Gniadek A, et al. Incidence, microbiological profile and risk factors of healthcare-associated infections in intensive care units: A 10-year observation in a district hospital in southern Poland. Int. J Environ. Res.Public Health 2018;15:112; Available from: doi:https://doi.org/10.3390/ ijerph15010112.
7. Vincent J-L, Rello J, Marshall J et al. International study of prevalence and outcomes of infection in intensive care units. EPIC II. JAMA. 2009;302(21): 2323-2329. Available from: doi: https://doi.org/10.1001/jama.2009.1754

8. Tomaszewski D, Rybicki Z, Duszynska W. The Polish Prevalence of Infection in Intensive Care (PPIC): A one-day point prevalence multicenter study. Adv Clin Exp Med. 2019, 28(7): 907-912 Available from: doi: https://doi.org/10. 17219/acem/94147.

9. Kubler A, Duszynska W, Rosenthal VD, et al. Device-associated infection rates and extra length of stay in an intensive care unit of a university hospital in Wroclaw, Poland: International Nosocomial Infection Control Consortium's (INICC) findings. J Crit Care. 2012;27:105 e5-10.

10. Dudeck MA, Weiner LM, Allen-Bridson K, et al. National Healthcare Safety Network (NHSN) report, data summary for 2012, device-associated module. Am J Infect Control. 2013:41:1148-66.

11. Rosenthal VD, Al-Abdely HM, El-Kholy AA, et al. International nosocomial infection control consortium (INICC) report, data summary of 50 countries for 2010-2015: device-associated module. Am J Infect Control. 2016:44(12): 1495-504. Available from:. https://doi.org/10.1016/j.ajic.2016.08.007.

12. Vincent J-L, Sakr Y, Singer M, Martin-Loeches J et al Prevalence and Outcomes of Infection Among patients in Intensive Care Units in 2017 JAMA; 2020.323(15: 1478-1487) Available from: doi:https://doi.org/10.1001/ jama.2020.2717

13. Zhang Y, Zhong Z-F, Chen S-X, Zhu D-R, et al. Prevalence of healthcareassociated infections and antimicrobial use in China: results from the 2018 point prevalence survey in 189 hospitals in Guangdong Province. Int J Infec Dis. 2019:89:179-84.

14. Magill SS, Edwards JR, Bamberg W, et al. Multistate point-prevalence survey of health care-associated infections. N Engl J Med. 2014;370:1198-208.

15. Deptuła A, Trejnowska E, Dubiel G, Zukowski M, et al. Prevalence of healthcare-associated infections in Polish adult intensive care units: summary data from the ECDC European Point Prevalence Survey of Hospital-associated Infections and Antimicrobial Use in Poland 2012-2014. J Hosp Infect. 2017;96:145-50.

16. Walaszek M, Rozanska A, Bulanda M, Wojkowska-Mach J, Polish Society of Hospital Infections Team. Epidemiology of healthcare-associated infections in Polish intensive care. A multicenter study based on active surveillance. Biomed Pap Med Fac Univ Palacky Olomouc Czech Repub. 2018;162:XX ; Available from. https://doi.org/10.5507/bp.2018.006.

17. Walaszek M, Rozanska A,Walaszek MZ, Wojkowska-Mach J, Polish Society of Hospital Infections Team. Epidemiology of Ventilator-Associated Pneumonia, microbiological diagnostics and length of antimicrobial treatment in the Polish Intensive Care Units in the years 2013-2015. BMC Infect Dis 2018; 18(1):308.Available from: doi:https://doi.org/10.1186/s12879-018-321.

18. Leblebicioglu $H$, Yalcin AN, Rosenthal VD, et al. Effectiveness of a multidimensional approach for prevention of ventilator-associated pneumonia in 11 adult intensive care units from 10 cities of Turkey: findings of the international nosocomial infection control consortium (INICC). Infection. 2013;41:447-56.

19. Mehta $Y$, Jaggi N, Rosenthal VD, et al. Effectiveness of a multidimensional approach for prevention of ventilator-associated pneumonia in 21 adult intensive-care units from 10 cities in India: findings of the international nosocomial infection control consortium (INICC). Epidemiol Infect. 2013;141: 2483-91.

20. Rosenthal VD, Rodrigues C, Alvarez-Moreno C, et al. Effectiveness of a multidimensional approach for prevention of ventilator-associated pneumonia in adult intensive care units from 14 developing countries of four continents: findings of the international nosocomial infection control consortium. Crit Care Med. 2012:40:3121-8.

21. Leblebicioglu $H$, Ozturk R, Rosenthal VD, et al. Impact of a multidimensional infection control approach on central line-associated bloodstream infections rates in adult intensive care units of 8 cities of Turkey: findings of the International Nosocomial Infection Control Consortium (INICC). Ann Clin Microbiol Antimicrob. 2013;12:10

22. Leblebicioglu H, Ersoz G, Rosenthal VD, et al. Impact of a multidimensional infection control approach on catheter-associated urinary tract infection rates in adult intensive care units in 10 cities of Turkey: international nosocomial infection control consortium findings (INICC). Am J Infect Control. 2013:41:885-91.

23. Kanj SS, Zahreddine N, Rosenthal VD, Alamuddin L, Kanafani Z, Molaeb B. Impact of a multidimensional infection control approach on catheterassociated urinary tract infection rates in an adult intensive care unit in 
Lebanon: international nosocomial infection control consortium (INICC) findings. Int J Infect Dis. 2013;17:e686-90.

24. Rosenthal VD, Bat-Erdene I, Gupta D, Belkebir S, et al. International nosocomial infection control consortium (INICC) report, data summary of 45 countries for 2012-2017. Device associated module. Am J Infect Control. 2019:1-10. (article in press). Available from. https://doi.org/10.1016/j.ajic. 2019.08.023.

25. European Centre for Disease Prevention and Control. European Centre for Disease Prevention and Control. Healthcare-associated infections acquired in intensive care units. In: ECDC Annual epidemiological report for 2017. Stockholm: ECDC, 2019. Available from: https://www.ecdc.europa.eu/en/ publications-data/healthcare-associated-infections-intensive-care-unitsannual-epidemiological-1.

26. Horan TC, Andrus M, Dudeck MA. CDC/NHSN surveillance definition of health care-associated infection and criteria for specific types of infections in the acute care setting. Am J Infect Control. 2008;36:309-32.

27. EUCAST. Breakpoint tables for interpretation of MICs and zone diameters. Version 6.0;; 2016. Available from: http://www.eucast.org/clinical_ breakpoints. (Accessed Jan 2016).

28. Duszynska W, Barteczko B, Kubler A. Monitoring of nosocomial infections using the HELICS network. Anestezjol Intens Ter. 2008;40(1):17-21 Article in Polish. PubMed PMID:19469093.

29. Vincent $J \mathrm{~L}$, Bihari DJ, Suter PM, et al. The prevalence of nosocomial infection in intensive care units in Europe. Results of the European prevalence of infection in intensive care (EPIC) study. EPIC international Advirsory committee. JAMA. 1995;274(8):639-44.

30. Duszynska W. Analysis of changes of bacterial flora at Intensive Care Units. Doctoral thesis. Wroclaw: Department of Anaesthesiology and Intensive Therapy, Wroclaw Medical University; 1998. p. 50-2.

31. European Centre for Disease Prevention and Control. Healthcare-associated infections acquired in intensive care units. In: ECDC Annual epidemiological report for 2016. Stockholm: ECDC, 2018. Available from https:/www.ecdc. europa.eu/en/publications-data/healthcare-associated-infections-intensivecare-units-annual-epidemiological-0,

32. Duszynska W, Rosenthal VD, Dragan B, et al. Ventilator-associated pneumonia monitoring according to the INICC project at one Centre. Anaesthesiol Intensive Ther. 2015;47(1):34-9. Available from. https://doi.org/ 10.5603/AIT.2015.0004.

33. Duszynska W, Rosenthal VD, Szczesny A, et al. Urinary tract infections in intensive care unit patients - a single-Centre, 3-year observational study according to the INICC project. Anaesthesiol Intensive Ther. 2016;48:1-6.

34. Rutkowska $\mathrm{K}$, Przybyla M, Misiolek H. Health-care associated infection in the newly-opened intensive care unit. Anaesthesiol Intensive Ther. 2013;45:62-6.

35. Al-Mousa HH, Omar AA, Rosenthal VD, et al. Device-associated infection rates, bacterial resistance, length of stay, and mortality in Kuwait: international nosocomial infection consortium findings. Am J Infect Control. 2016:44(4):444-9.

36. Chavarria Ugalde O, Fernandez Hidalgo R, Rosenthal VD, et al. Deviceassociated infection rates, bacterial resistance, length of stay, and mortality in intensive care units of Costa Rica: findings of the international nosocomial infection control consortium (INICC). Can J Infect Control. 2016; 31(1):28-34

37. Gan CS, Rai V, Rosenthal VD, et al. Multicenter study in Malaysia: impact of a multidimensional international nosocomial infection control consortium (INICC) approach on ventilator-associated pneumonia rates and mortality in intensive care units. Can J Infect Control. 2016;31:230-6.

38. Wieder-Huszla S. Monitoring of nosocomial infections in intensive care units. Ann Acad Med Stetin. 2010;56:20-9 Article in Polish. PMID: 220536

39. Weiner LM, Webb AK, Limbago B, et al. Antimicrobial-resistant pathogens associated with healthcare-associated infections: summary of data reported to the National Healthcare Safety Network at the Centre for Disease Control and Prevention, 2011-2014. Infect Control Hosp Epidemiol. 2016;37:1288301.

40. Agodi A, Zarrilli R, Barchitta M, et al. Alert surveillance of intensive care unitacquired Acinetobacter infections in a Sicilian hospital. Clin Microbiol Infect. 2006;12:241-7.

41. Villar M, Cano ME, Gato E, et al. Epidemiologic and clinical impact of Acinetobacter baumannii colonization and infection: a reappraisal. Medicine (Baltimore). 2014;93:202-10.

42. European Centre for Disease Prevention and Control. Surveillance of antimicrobial resistance in Europe 2018. Stockholm: ECDC 2019. Available from: https://www.ecdc.europa.eu/sites/default/files/documents/ surveillance-antimicrobial-resistance-Europe-2018.pdf

43. Duszynska W, Litwin A, Rojek S, Szczesny A, et al. Analysis of Acinetobacter baumannii hospital infections in patients treated at the intensive care unit of the University Hospital, Wroclaw, Poland: a 6-year, single-center, retrospective study. Infect Drug Resist. 2018;11:629-35. Available from. https://doi.org/10.2147/IDR.S162232.

44. Al-Abdely HM, Alshehri AD, Rosenthal VD, et al. Prospective multicentre study in intensive care units in five cities from the Kingdom of Saudi Arabia: impact of the international nosocomial infection control consortium (INICC) multidimensional approach on rates of central line -associated bloodstream infection. J Infect Prev. 2017;18(1):25-34.

45. Al-Mousa HH, Omar AA, Rosenthal VD, et al. Impact of the international nosocomial infection control consortium (INICC) multidimensional approach on rates of ventilator-associated pneumonia in intensive care units of two hospitals in Kuwait. J Infect Prev. 2018;19(4):168-76.

46. Rosenthal VD, Pawar M, Leblebicioglu H, Navoa-Ng JA, et al. Impact of the international nosocomial infection control consortium (INICC) multidimensional hand hygiene approach over 13 years in 51 cities of 19 limited -resource countries from Latin America, Asia, the Middle East, and Europe. Infect Control Hosp Epidemiol. 2013;34(4):415-23.

47. Pittet $D$, Allegranzi B, Boyce J. World Health Organization world Alliance for patient safety first global patient safety challenge Core Group of experts. The World Health Organization guidelines on hand hygiene in health care and their consensus recommendations. Infect Control Hosp Epidemiol. 2009;30(7):611-22

\section{Publisher's Note}

Springer Nature remains neutral with regard to jurisdictional claims in published maps and institutional affiliations.

Ready to submit your research? Choose BMC and benefit from:

- fast, convenient online submission

- thorough peer review by experienced researchers in your field

- rapid publication on acceptance

- support for research data, including large and complex data types

- gold Open Access which fosters wider collaboration and increased citations

- maximum visibility for your research: over $100 \mathrm{M}$ website views per year

At $\mathrm{BMC}$, research is always in progress.

Learn more biomedcentral.com/submissions 